\title{
Motives and Satisfaction of Radio Listeners in The New Media Era (Cases Study on Dhara FM Radio Listenes in Pariaman)
}

\author{
Fitriani Ayu Lestari ${ }^{1}$; Sarwan²; Mulianti Syas ${ }^{3}$; Prima Kurniati Hamzah ${ }^{4}$ \\ Imam Bonjol Islamic State University \\ ${ }^{1}$ Email : ayulestari12fitriani@gmail.com \\ ${ }^{2}$ Email : sarwanma@uinib.ac.id \\ ${ }^{3}$ Email : mulyantisyas@uinib.ac.id \\ ${ }^{4}$ Email: primakurniati@uinib.ac.id
}

\begin{abstract}
Radio is the oldest and most flexible electronic mass media. The new media as mentioned has resulted in the radio being abandoned by the audience and turning to choosing new media as information and entertainment. Survey conducted by a Nielsen survey institute in 2014, stated that every year radio listeners decreased by 3\%. The purpose of this study is to find out and explain the motives and satisfaction of the Dhara FM radio listeners in the city of Pariaman in listening to radio in the new media era. This study uses descriptive quantitative research methods. Describe systematically, factually, and accurately about the facts and nature of the population and try to describe phenomena in detail. The data source is a questionnaire. The analysis used is descriptive analysis. Results that can be taken from this study are entertainment motives and the motives of interaction and social integration have a significant influence in influencing the satisfaction of the Dhara FM radio listeners Pariaman. Satisfaction obtained by listeners can be seen from the persistence of radio listeners in listening to the radio. Motives have a strong enough influence to achieve listener satisfaction.
\end{abstract}

Keyword : motivation; satifaction; new media

\begin{abstract}
ABSTRAK
Radio adalah media massa elektronik tertua dan sangat luwes Hadirnya media baru seperti yang telah disebutkan mengakibatkan radio mulai ditinggalkan oleh khalayaknya beralih memilih media baru sebagai media informasi dan hiburan. Survey yang dilakukan oleh sebuah lembaga survey Nielsen pada tahun 2014, menyebutkan bahwa setiap tahunnya pendengar radio mengalami penurunan hingga 3\%. Tujuan penelitian ini yaitu untuk mengetahui dan menjelaskan motif dan kepuasan pendengar radio Dhara FM kota Pariaman dalam mendengarkan radio di era media baru. Penelitian ini menggunakan metode penelitian kuantitatif deskriptif. Mendeskripsikan secara sistematis, faktual, dan akurat mengenai faktafakta dan sifat populasi dan mencoba menggambarkan fenomena secara detail. Sumber data berupa angket. Analisis yang digunakan ialah deskriptif analisis. Hasil yang dapat diambil dari penelitian ini adalah motif hiburan dan motif interaksi dan integrasi sosial memiliki pengaruh yang signifikan dalam mempengaruhi kepuasan pendengar radio Dhara FM kota Pariaman. Kepuasan yang diperoleh pendengar terlihat dari bertahannya pendengar radio dalam mendengarkan radio. Motif memiliki pengaruh yang cukup kuat dalam mencapai kepuasan pendengar.
\end{abstract}

Kata Kunci : motif; kepuasan; media baru 


\section{PENDAHULUAN}

Komunikasi merupakan faktor penting dalam kehidupan manusia karena komunikasi dapat memperlancar hubungan antar manusia sebagai makhluk sosial. Menurut Harold D. Laswell, menurutnya komunikasi adalah proses penyampaian pesan oleh komunikator kepada komunikan melalui media yang menimbulkan efek tertentu. "Says What In Which Channel To Whom With What Effect", dari pernyataan tersebut menunjukkan bahwa komunikasi meliputi 5 (lima) unsur penting yakni, Who (siapa), Says What (berkata apa), In Which Channel (melalui saluran apa), To Whom (kepada siapa), dan With What Efect (melalui efek apa). Onong (Uchjana Effendy, 2006).

Komunikasi dilihat dari jumlah komunikan terdiri dari komunikasi pribadi, komunikasi kelompok, dan komunikasi massa. Komunikasi massa merupakan sejenis kekuatan sosial yang dapat menggerakkan proses sosial ke arah suatu tujuan yang telah ditetapkan terlebih dahulu. (Uchjana Effendy, 2006, 54). Definisi komunikasi massa yang dikemukakan oleh Bittner, yakni pesan yang dikomunikasikan melalui media massa pada sejumlah besar orang. (Elvinaro Ardianto, 2007:25). Dari definisi tersebut dapat diketahui bahwa komunikasi massa itu harus menggunakan media massa.

Media massa adalah sarana atau peralatan yang dapat menjangkau massa sebanyak-sebanyaknya dan area yang seluas-luasnya (Denis McQuail, 2012:13) Berdasarkan bentuknya media massa dapat dibedakan menjadi dua, media cetak seperti koran dan majalah, dan media elektronik seperti televisi dan radio.

Radio menurut ensiklopedi Indonesia yaitu penyampaian informasi dengan pemanfaatan gelombang elektromagnetik bebas yang memiliki frequensi kurang dari $300 \mathrm{GHz}$ (panjang gelombang lebih besar dari $1 \mathrm{~mm}$ ).[Wikipedia, diakses pada 18 Desember 2016 Pukul 19.21 WIB]

Undang-undang Penyiaran No. 32/2002 menjelaskan kegiatan pemancarluasan siaran melalui sarana pemancaran dan/atau sarana transmisi di darat, di laut atau di antariksa dengan menggunakan spektrum frekuensi radio melalui udara, kabel, dan/atau media lainnya untuk dapat diterima secara serentak dan bersamaan oleh masyarakat dengan perangkat penerima siaran, yang dilakukan secara teratur dan berkesinambungan.

Radio adalah media massa elektronik tertua dan sangat luwes (Denis McQuail, 2012:123). Radio di Indonesia terbagi atas dua, yakni radio pemerintah dan radio non pemerintah (radio swasta). Radio pemerintah dikenal dengan nama Radio Republik Indonesia (RRI) yang didirikan pada tahun 11 September 1945. Sebagai sarana penyambung informasi pemerintahan kepada masyarakat Indonesia.

Radio swasta di Indonesia berkembang sejak tahun 1966. Radio swasta di Indonesia hadir atas dasar kecintaan orang-orang pada siaran radio sehingga mendirikan radio swasta sebagai wadah berkreatifitas, sejak saat itu perkembangan radio swasta di Indonesia meningkat. Pada tahun 1974 terdapat 330 radio swasta di Indonesia. Bahkan jumlah radio swasta di Indonesia sempat menyentuh angka 449 stasiun radio. Radio mencapai puncak kejayaannya di Indonesia pada tahun 1980

Pada tahun 1990-an menjadi awal perkembangan teknologi media komunikasi dan informasi. Hal ini membawa era teknologi komunikasi saat ini pada era New Media (Media Baru). Media baru didefinisikan sebagai produk dari komunikasi yang termediasi teknologi yang terdapat bersama dengan komputer digital.[ Creeber dan Martin, Digital cultures, (Berkshire: Open University Press, 2009), h. 2] Media baru 
merupakan media yang menggunakan internet, media online berbasis teknologi, berkarakter fleksibel, berpotensi interaktif dan dapat berfungsi secara privat maupun secara publik (Mondry, 2008: 13) Diantara macam-macam media baru yang tengah berkembang saat ini ialah : Facebook, Youtube, Twitter dan lain-lain yang biasa disebut dengan media sosial.

Hadirnya media baru seperti yang telah disebutkan mengakibatkan radio mulai ditinggalkan oleh khalayaknya. Banyak khalayak radio atau biasa disebut dengan pendengar radio beralih memilih media baru sebagai media informasi dan hiburan.

Survey yang dilakukan oleh sebuah lembaga survey Nielsen pada tahun 2014, menyebutkan bahwa setiap tahunnya pendengar radio mengalami penurunan hingga 3\%. (Harianjogja.com diakses pada 17 Januari 2017, pada pukul 21.05 WIB)

Jika hasil survey Nielsen ini dijadikan landasan, maka sekitar tahun 2013 pendengar radio sudah habis. Namun, kenyataannya masih ada radio swasta yang masih aktif. Hal ini bisa dilihat dari beberapa radio besar di Indonesia yang masih eksis, seperti radio Prambors FM yang berada di Jakarta. Pendengarnya bisa dilihat dari banyaknya orang yang berpartisipasi di akun media sosial radio tersebut. Tidak hanya radio yang berada di kota besar saja yang masih eksis di era media baru saat ini, tetapi juga di kotakota kecil. Salah satunya ialah radio yang berada di kota Pariaman, Sumatera Barat.

Kota Pariaman memiliki luas daerah $73.360 \mathrm{KM}^{2}$ dan jumlah penduduk sebanyak 97.901 orang.[Wikipedia, diakses pada 18 desember 2016, Pada Pukul 20.18 WIB ] Pada tahun 2012, terdapat 6 stasiun radio swasta di Kota Pariaman, namun saat ini Kota Pariaman hanya memiliki 2 stasiun radio swasta yang masih aktif, yaitu Radio Damai FM dan Radio Dhara FM. Dan alasan penulis memilih Radio Dhara FM dikarenakan
Radio Dhara FM merupakan radio swasta yang memiliki pendengar yang beragam.

Berdasarkan pengamatan awal penulis 2 bulan (3 Oktober- 3 Desember), Radio Dhara FM Kota Pariaman memilliki banyak pendengar setia. Pendengar radio Dhara FM dapat dibedakan menjadi dua, yakni pendengar aktif dan pendengar pasif. Pendengar aktif ialah pendengar yang sering yang berpartisipasi dalam program-program radio yang di sediakan. Pendengar berpartisipasi dengan dua cara yakni pertama, melalui telepon. Pendengar langsung menelpon ketika acara on air. Selain itu, pendengar juga bisa bepartisipasi melalui media sosial yang telah disediakan oleh radio.

Temuan lapangan bahwa pendengar aktif Radio Dhara FM cukup banyak. Hal ini dapat dilihat dari banyaknya pendengar yang ikut berpartisipasi pada program interaktif yang disediakan radio Dhara FM. Program Radio Dhara FM selalu berdurasi 3 jam termasuk program interaktifnya, setiap segmen berdurasi $\pm 10-15$ menit dan ada 4-5 orang penelpon yang ikut berpartisipasi disetiap segmennya. Selain penelpon, juga ada beberapa komentar pendengar di akun Facebook Radio Dhara FM Kota Pariaman yang ikut juga berpatisipasi dalam program tersebut.

Pendengar pasif yakni pendengar radio yang tidak ikut berpartisipasi dalam program radio namun hanya mendengarkan program radio yang disiarkan. Hal ini penulis dapatkan berdasarkan pengamatan penuli ketika berbelanja di pasar Pariaman beberapa toko memasang radio dan mendengarkan radio Dhara FM sebagai media Hiburan. Selain itu, beberapa warung-warung kopi yang berada dilingkungan tempat tinggal penulis juga memasang radio dan mendengarkan Radio Dhara FM. Rumahrumah masyarakat yang bekerja sebagai penjahit mukena di sekitar tempat tinggal penulis juga mendengarkan Radio Dhara FM sebagai media hiburan. 
Pendengar yang bertahan mendengarkan radio di era media baru menunjukkan adanya prilaku pemilihan media oleh khalayak. Pemilihan media oleh khalayak ini merupakan pembahasan yang dikaji dalam teori uses and gratifications. Teori uses and gratifications ialah salah satu teori komunikasi massa.

Teori ini menunjukkan bahwa permasalahan utamanya bukan pada bagaimana cara media mengubah sikap dan perilaku khalayak, tetapi lebih kepada bagaimana media memenuhi kebutuhan pribadi dan sosial khalayak, sehingga sasarannya ialah pada khalayak yang aktif, yang memang menggunakan media untuk mencapai tujuan khusus. (Edi Santoso dan Mite Setiansah, 2010:108) Inti dari teori uses and gratifications adalah khalayak pada dasarnya menggunakan media massa berdasarkan motif-motif tertentu. (Kryantono, 2006:207)

Pendengar radio di era media baru saat ini menunjukkan bahwa khalayak yang memilih media. Hal ini sesuai dengan teori uses and gratifications. Sehingga penggunaan teori ini sejalan dengan permasalahan yang diteliti

Fenomena pendengar radio di era media baru saat ini menarik dan penting untuk ditelusuri secara ilmiah, terutama penjelasan tentang alasan, motif, dan kepuasan para pendengar radio dalam menggunakan radio sebagai media hiburan dan informasi.

\section{METODE PENELITIAN}

Penelitian ini menggunakan pendekatan kuantitatif, karena pendekatan kuantitatif dapat menghasilkan data yang akurat setelah perhitungan yang tepat. Pendekatan kuantitatif merupakan salah satu pendekatan dalam penelitian yang lebih ditekankan pada data yang dapat dihitung untuk menghasilkan penafsiran kuantitatif yang kokoh (Salam, 2006:13)
Pendekatan kuantitatif bertujuan menggambarkan atau menjelaskan suatu masalah yang hasilnya dapat digeneralisasikan. Dengan demikian tidak terlalu mementingkan kedalaman data atau analisis. Peneliti lebih mementingkan aspek keluasan data sehingga hasil penelitian dianggap merupakan representasi dari seluruh populasi. (Kriyantono, 2009:55)

Populasi dari penelitian ini ialah seluruh pendengar Radio Dhara FM Kota Pariaman, yakni pendengar aktif. Populasi pendengar aktif radio Dhara FM berjumlah 127 orang. Hal ini dilihat dari jumlah anggota fansclub Radio Dhara FM. Sampel penelitian ini adalah total sampling yakni pengambilan seluruh populasi untuk dijadikan sampel (Sugiyono, 2007)

HASIL DAN PEMBAHASAN

1. Data Responden Berdasarkan Jenis Kelamin

\begin{tabular}{llll}
\hline No. & $\begin{array}{l}\text { Jenis } \\
\text { Kelamin }\end{array}$ & Jumlah & Persentase \\
\hline 1. & Perempuan & 79 & $62,2 \%$ \\
\hline 2. & Laki-laki & 48 & $37,8 \%$ \\
\hline Jumlah & $\mathbf{1 2 7}$ & $\mathbf{1 0 0 \%}$ \\
\hline \multicolumn{3}{c}{ Tabel 9. Data Responden Berdasarkan Jenis } \\
\multicolumn{4}{c}{ Kelamin } \\
\hline
\end{tabular}

Berdasarkan data tersebut dapat diketahui jumlah pendengar radio di dominasi oleh perempuan yakni sejumlah 79 orang $(62,2 \%)$ sedangkan laki-laki sebanyak 48 oramg $(37,8 \%)$.

2. Data Responden Berdasarkan Usia

No. Rentang Jumlah Persentase Usia

\begin{tabular}{llll}
\hline 1. & $20-30$ & 23 & $18 \%$ \\
\hline 2. & $31-40$ & 49 & $38,6 \%$ \\
\hline 3. & $41-50$ & 38 & $30 \%$ \\
\hline 4. & $51-60$ & 14 & $11 \%$ \\
\hline 5. & $61-70$ & 3 & $2,4 \%$ \\
\hline \multicolumn{2}{l}{ Jumlah } & $\mathbf{1 2 7}$ & $\mathbf{1 0 0 \%}$
\end{tabular}

Tabel 10. Data Responden Berdasarkan Usia 
Berdasarkan data tersebut, dapat diketahui jumlah pendengar radio di dominasi oleh pendengar pada rentang usia 31-40 tahun sebanyak 49 orang $(38,6 \%)$ lalu pendengar usia 41-50 tahun sebanyak 38 orang (30\%). Selanjutnya pendengar usia 20-30 tahun sebanyak 23 orang (18\%), pendengar usia 51-60 tahun sebanyak 14 orang (11\%) dan terakhir pendengar usia 61-70 tahun sebanyak 3 orang $(2,4 \%)$.

3. Data Responden Berdasarkan Waktu Mendengarkan

\begin{tabular}{llll}
\hline No. & Waktu & Jumlah & Persentase \\
\hline 1. & Pagi & 50 & $39,3 \%$ \\
\hline 2. & Siang & 40 & $31,4 \%$ \\
\hline 3. & Malam & 20 & $16 \%$ \\
\hline 4. & $\begin{array}{l}\text { Setiap } \\
\text { Saat }\end{array}$ & 17 & $13,3 \%$ \\
\hline
\end{tabular}

Jumlah $\quad 127 \quad 100 \%$

Tabel 11. Data Responden Berdasarkan Waktu Mendengarkan

Berdasarkan data tersebut, diketahui pendengar radio mulai mendengarkan radio paling banyak pada pagi hari sebanyak 50 orang $(39,3 \%)$, sedangkan pada siang hari pendengar radio sebanyak 40 orang $(31,4 \%)$. Lalu sisanya mendengarkan radio pada malam hari sebanyak 20 orang (16\%). Dan 17 orang $(13,3 \%)$ mendengarkan radio setiap saat.

4. Data responden berdasarkan durasi mendengarkan radio

\begin{tabular}{|c|c|c|c|}
\hline No. & Durasi & Jumlah & Persentase \\
\hline 1. & $\begin{array}{l}\leq \\
\text { Jam }\end{array}$ & 26 orang & $20,4 \%$ \\
\hline 2. & $\begin{array}{l} \pm \\
\text { Jam }\end{array}$ & 11 orang & $8,6 \%$ \\
\hline 3. & $\begin{array}{l}\geq \\
\text { Jam }\end{array}$ & 90 orang & $71 \%$ \\
\hline \multicolumn{2}{|c|}{ Jumlah } & 127 Orang & $100 \%$ \\
\hline
\end{tabular}

Tabel 12. Data Responden Berdasarkan Durasi Mendengarkan Radio

Berdasarkan data tersebut, dapat dilihat 90 orang (71\%) responden mendengarkan radio lebih dari 6 jam. Sedangkan 26 orang $(20,4 \%)$ responden mendengarkan radio kurang dari 3 jam. 11 orang $(8,6 \%)$ responden mendengarkan radio selama kurang lebih 6 jam.

5. Data responden berdasarkan daerah

\begin{tabular}{|c|c|c|c|c|}
\hline \multirow[t]{2}{*}{ No. } & \multirow[t]{2}{*}{ Daerah } & \multicolumn{2}{|c|}{ Jumlah } & \multirow{2}{*}{$\begin{array}{c}\text { Persen } \\
\text { tase }\end{array}$} \\
\hline & & $\begin{array}{l}\text { Laki- } \\
\text { laki }\end{array}$ & Perempuan & \\
\hline 1. & $\begin{array}{l}\text { Kota } \\
\text { Pariaman }\end{array}$ & 24 orang & 35 orang & $46,4 \%$ \\
\hline 2. & $\begin{array}{l}\text { Kab. } \\
\text { Padang } \\
\text { Pariaman }\end{array}$ & $\begin{array}{l}17 \\
\text { orang }\end{array}$ & 36 orang & $41,7 \%$ \\
\hline 3. & $\begin{array}{l}\text { Kab. } \\
\text { Agam }\end{array}$ & 3 orang & 4 orang & $5,5 \%$ \\
\hline 4. & $\begin{array}{l}\text { Kab. } \\
\text { Pessel }\end{array}$ & 2 orang & 1 orang & $2,4 \%$ \\
\hline 5. & $\begin{array}{l}\text { Kota Bkt } \\
\text { tinggi }\end{array}$ & 2 orang & 3 orang & $4 \%$ \\
\hline \multicolumn{2}{|c|}{ Jumlah } & 48 & 79 & $100 \%$ \\
\hline
\end{tabular}

Berdasarkan data dari tabel di atas, pendengar radio Dhara FM kota Pariaman paling banyak berada di kota Pariaman yaitu sebanyak 46, 4\% dengan pendengar laki-laki sebanyak 24 orang dan perempuan sebanyak 35 orang. Sedangkan daerah yang paling banyak selanjutnya ada di daerah kabupaten Padang Pariaman yaitu sebanyak 41,7\% dengan pendengar laki-laki sebanyak 17 orang dan perempuan sebanyak 36 orang. Sisanya berada di kab. Agam 5,5\% dengan pendengar laki-laki sebanyak 3 orang dan perempuan sebanyak 4 orang. Selanjutnya di kota Bukit Tinggi sebesar $4 \%$ dengan pendengar laki-laki 2 orang dan perempuan sebanyak 3 orang. Dan terakhir berada di kab. Pesisir selatan dengan persentase sebesar $2,4 \%$ dengan pendengar laki-laki sebanyak 2 orang dan 1 orang pendengar perempuan.

6. Data responden berdasarkan pekerjaan

\begin{tabular}{llcc}
\hline No. & Pekerjaan & Jumlah & Persentase \\
\hline 1. & $\begin{array}{l}\text { Ibu Rumah } \\
\text { Tangga }\end{array}$ & $\begin{array}{c}36 \\
\text { Orang }\end{array}$ & $28,3 \%$ \\
\hline
\end{tabular}




\begin{tabular}{|c|c|c|c|}
\hline 2. & Penjahit & $\begin{array}{c}17 \\
\text { Orang }\end{array}$ & $13,3 \%$ \\
\hline 3. & Pedagang & $\begin{array}{c}38 \\
\text { Orang }\end{array}$ & $30 \%$ \\
\hline 4. & Pegawai & 6 Orang & $5 \%$ \\
\hline 5. & $\begin{array}{l}\text { Penyedia } \\
\text { Jasa } \\
\text { (Bengkel, } \\
\text { Las, dll) }\end{array}$ & $\begin{array}{c}12 \\
\text { Orang }\end{array}$ & $9,4 \%$ \\
\hline 6. & Petani & $\begin{array}{c}18 \\
\text { Orang }\end{array}$ & $14 \%$ \\
\hline & Jumlah & $\begin{array}{c}127 \\
\text { Orang }\end{array}$ & $100 \%$ \\
\hline
\end{tabular}

Berdasarkan tabel diatas, pendengar radio Dhara FM kota Pariaman mayoritas bekerja sebagai pedagang yakni sebanyak 38 orang (30\%). Selanjutnya ibu rumah tangga sebanyak 28 orang $(28,3 \%)$. Petani sebanyak 18 orang dengan persentase sebesar 14\%. Penjahit sebanyak 17 orang (13,3\%). Penyedia jasa sebesar 12 orang $(9,4 \%)$. Dan terakhir pegawai sebanyak 6 orang (5\%).

7. Hubungan antar variabel independen dengan dependen

\begin{tabular}{|c|c|c|}
\hline No & Variabel & R Square \\
\hline 1 & Motif Informasi & 0,366 \\
\hline 2 & $\begin{array}{ll}\text { Motif } & \text { Indetitas } \\
\text { Pribadi } & \end{array}$ & $0,361$. \\
\hline 3 & $\begin{array}{l}\text { Motif Integrasi dan } \\
\text { interasksi sosial }\end{array}$ & 0,491 \\
\hline 4 & Motif Hiburan & 0,403 \\
\hline
\end{tabular}

a. Motif Informasi (Variabel X1)

$$
\text { Jika motif informasi (X1) }
$$
dihubungkan dengan kepuasan, maka diperoleh angka 0,366. Hal ini berarti, korelasi antara motif informasi (variabel $\mathrm{X} 1$ ) dengan kepuasan rendah. Dari hasil nilai korelasi motif informasi diperoleh nilai positif, ini menunjukkan adanya korelasi yang signifikan. Sehingga jika radio Dhara FM Kota Pariaman menambah segmen/acara yang berkaitan dengan informasi maka kepuasan pendengar juga akan meningkat. b. Motif Indetitas Pribadi (Variabel X2)

Pada Motif Identitas Pribadi (variabel X2) dihubungkan dengan kepuasan, maka diperoleh angka 0,361. Hal ini berarti, korelasi antara motif identitas pribadi (variabel X2) rendah. Dari hasil nilai korelasi yang diperoleh nilai positif, menunjukkan adanya korelasi yang signifikan. Sehingga jika semakin besar segmen mengenai hal yang membantu identitas personal pendengar yang diberikan radio Dhara FM Kota Pariaman maka kepuasan pendengar juga akan meningkat.

c. Motif Integrasi dan interasksi sosial (Variabel X3)

Pada motif integrasi dan interasksi sosial (variabel X3) dihubungkan dengan kepuasan, diperoleh angka 0,491. Hal ini berarti korelasi antara Motif Integrasi dan interaksi sosial (variabel X3) dengan kepuasan cukup kuat. Serta hasil nilai korelasi yang diperoleh nilai positif menunjukkan adanya korelasi yang signifikan. Sehingga jika semakin besar integrasi dan interaksi sosial yang diberikan radio Dhara FM Kota Pariaman kepada pendengar, maka kepuasan pendengar juga akan meningkat.

d. Motif Hiburan (Variabel X4)

Pada variabel X4 (Motif hiburan) dihubungkan dengan kepuasan, diperoleh angka 0,403. Hal ini berarti korelasi antara motif hiburan (variabel X4) dengan kepuasan cukup kuat. Serta hasil nilai korelasi diperoleh nilai positif menunjukkan adanya korelasi yang signifikan. Sehingga jika semakin besar segmen hiburan yang diberikan radio Dhara FM Kota Pariaman kepada pendengar, maka kepuasan pendengar juga akan meningkat.

8. Variabel dominan yang mempengaruhi kepuasaan

\begin{tabular}{lllll}
\hline No & Variabel & $\begin{array}{l}\text { B } \\
\text { Beta }\end{array}$ & $\begin{array}{l}\boldsymbol{H} \\
\text { Hitung }\end{array}$ & $\begin{array}{l}\boldsymbol{P} \\
\text { Value }\end{array}$ \\
\hline 1 & Motif Informasi & 0,153 & 1,864 & 0,065 \\
\hline 2 & $\begin{array}{l}\text { Motif Indetitas } \\
\text { Pribadi }\end{array}$ & 0,092 & 1,095 & 0,276 \\
\hline 3 & $\begin{array}{l}\text { Motif Integrasi } \\
\text { dan interasksi } \\
\text { sosial }\end{array}$ & 0,340 & 4,214 & 0,000 \\
& & & & \\
\hline
\end{tabular}


4 Motif Hiburan $\quad 0,264 \quad 3,449 \quad 0,001$

Tabel 16. Hubungan masing- masing Variabel independen dengan variable dependen

Dengan menggunakan uji $\mathrm{T}$, diperoleh nilai signifikansi motif informasi (variabel $\mathrm{X} 1$ ) sebesar 0,065 serta nilai $\mathrm{T}$ hitung sebesar 1,864 . Artinya nilai signifikansi variabel X1 lebih besar dari pada 0,05. Sedangkan nilai $\mathrm{T}$ hitung variabel X1 lebih kecil jika dibandingakan dengan nilai $\mathrm{T}$ tabel 1,979. Berdasarkan hasil tersebut dapat disimpulkan bahwa motif informasi tidak berpengaruh signifikan terhadap kepuasan pendengar radio di era media baru, sehingga hipotesis nol (H0) diterima dan Ha ditolak.

Sedangkan pada motif indetitas personal (variabel X2) diperoleh data nilai sigfinikansi sebesar 0,276 serta nilai $\mathrm{T}$ hitung sebesar 1,095. Artinya nilai signifikansi variabel X2 lebih besar dari pada 0,05. Sedangkan nilai $\mathrm{T}$ hitung variabel X2 lebih kecil jika dibandingakan dengan nilai $\mathrm{T}$ tabel 1,979. Sehingga dapat diketahui bahwa motif identitas personal tidak berpengaruh terhadap kepuasan pendengar radio di era media baru, sehingga hipotesis nol (Ho) diterima dan Ha ditolak.

Sedangkan pada motif interaksi dan integrasi sosial (variabel X3) dalam uji $\mathrm{T}$, diperoleh data nilai signifikansi sebesar 0,00 dan nilai $\mathrm{T}$ hitung 4,214. Artinya nilai signifikansi variabel X3 lebih kecil dari pada 0,05 . Sedangkan nilai $T$ hitung variabel X3 lebih besar jika dibandingakan dengan nilai $\mathrm{T}$ tabel 1,979. Sehingga dapat diketahui bahwa motif interaksi dan integrasi sosial berpengaruh terhadap kepuasan pendengar radio di era media baru, maka $\mathrm{HO}$ ditolak dan Ha diterima.

Sedangkan pada motif hiburan (variabel X4) dalam uji T, diperoleh data signifikansi sebesar 0,001 dan nilai $\mathrm{T}$ hitung sebesar 3,449. Artinya nilai signifikansi variabel X4 lebih kecil dari pada 0,05. Sedangkan nilai $\mathrm{T}$ hitung variabel X4 lebih besar jika dibandingakan dengan nilai $\mathrm{T}$ tabel 1,979. Sehingga dapat diketahui bahwa motif hiburan berpengaruh terhadap kepuasan pendengar radio di era media baru, maka $\mathrm{HO}$ ditolak dan Ha diterima.

\section{KESIMPULAN}

Adapun kesimpulan dari penelitian ini adalah:

1. Penggunaaan radio di era media didasari beberapa motif. Diantaranya ialah motif informasi, motif identitas personal, motif interaksi dan integrasi sosial, dan motif hiburan. Namun, Motif hiburan dan motif interaksi dan integrasi sosial memiliki pengaruh yang signifikan dibandingkan dengan motif informasi dan motif identitas personal.

2. Pendengar radio Dhara FM kota Pariaman mendengarkan radio di era media baru dikarenakan adanya kebutuhan terhadap motif hiburan dan interaksi dan integrasi sosial. Kebutuhan ini terpenuhi oleh radio Dhara FM kota Pariaman sehingga menimbulkan kepuasan terhadap pendengar. kepuasan yang didapatkan oleh pendengar menjadi alasan bagi pendengar radio Dhara FM kota Pariaman masih mendengarkan radio di era media baru.

3. Berdasarkan uji F, motif informasi, identitas personal, interaksi dan integrasi sosial serta motif hiburan secara simultan memiliki pengaruh terhadap kepuasan pendengar. Sehingga semakin besar, motif pendengar yang terpenuhi oleh radio, maka semakin besar pula kepuasan yang diperoleh oleh pendengar.

\section{DAFTAR KEPUSTAKAAN}

Creeber dan Martin, Digital cultures, Berkshire: Open University Press, 2009.

Denis McQuail, Teori Komunikasi Massa, Jakarta: Salemba Humanika, 2012.

Dokumentasi Kominfo Kota Pariaman 17 Oktober 2016.

Edi Santoso dan Mite Setiansah, Teori Komunikasi, Yogyakarta: Graha Ilmu, 2010.

Elvinaro Ardianto,et al, Komunikasi Massa Suatu Pengantar Edisi Revisi, Bandung: Simbiosa Rekatam Media, 2007.

Erwan Agu Purwanto dan Dyah Ratih Sulistyastuti, Metode Penelitian Kuantitatif, Yogyakarta: Gavamedia, 2011. 
Harley Prayudha, Radio Suatu Pengantar untuk Wacana dan Praktik Penyiaran, Malang: Bayu Media Publshing, 2004.

Fatmasari Ningrum, Sukses Menjadi Penyiar, Scriptwriter, dan Reporter, Jakarta: Penebar Swadaya, 2007.

Harianjogja.com diakses pada 17 Januari 2017, pada pukul 21.05 WIB.

Http://Ilmusosial.Net/Perkembangan-Radio-

Di-Indonesia.Html, diakses pada 18

Desember 2016, pukul 20.05 WIB.

Hasan Asy'ari Oramahi, Jurnalistik Radio, Jakarta : Erlangga, 2012.

I Gusti Ngurah Agung, Statistik: Analisis Hubungan Kausal Berdasarkan Data Kategorik, Jakarta: Rajagrafindo Persada, 2002.

Imam Ghozali, Aplikasi Analisis Multivariate dengan Program SPSS, Semarang : BPUNDIP, 2009.

Indrawan WS, Kamus Besar Bahasa Indonesia, Jakarta: Balai Pustaka, 1998.

Jalaludin Rahmat, Metode Penelitian Komunikasi, Bandung: Rosdakarya, 2007.

M. Sonny Sumarsono, Metode Riset Sumber Daya Manusia, Yogyakarta: Graha Ilmu, 2004.

Masduki, Menjadi Broadcaster Profesional, Yogyakarta : Pustaka Populer LKiS, 2004.

Mohammad Mulyadi, Penelitian Kuantitatif dan Kualitaif, Jakarta: Publica Institute, 2010.

Mondry, Pemahaman Teori dan praktik Jurnalistik, Bogor: Ghalia Indonesia, 2008.

Nurani Soyomukti, Pengantar Ilmu Komunikasi, Jakarta : Ar -Ruzz, 2010.

Nurudin, Pengantar Komunikasi Massa, Jakarta: Raja Grafindo Persada, 2007.

Onong Uchjana Effendy, Ilmu Komunikasi; Teori dan Praktek, Bandung: Remaja Rosda Karya, 2006.

Onong Uchjana Effendy, Radio Siaran dan Praktik, Bandung : Alumni, 1990.
Onong Uchjana Effendy, Ilmu, Teori Dan Filsafat Komunikasi, Bandung, $\mathrm{Pt}$ Citra Aditya Bakti, 2003.

Pangestu Subagyo dan Djarwanto Ps, Statistika Induktif, Yogyakarta: BPFEYpgyakarta, 2005.

Rahmat Kriyantono, Teknik Praktis Riset Komunikasi. Jakarta; Kencana. 2009.

Richard West and Lynn H. Turner, Pengantar Teori Komunikasi : Analisis dan Aplikasi, Jakarta, Salemba Humanika, 2010.

Rudy Setiawan, Kekuatan New Media Dalam Membentuk Budaya Populer Di Indonesia, eJournal Ilmu Komunikasi, Samarinda : Universitas Mulawarman, 2013.

Sofyan Yamin dan Heri Kurniawan, Teknik Analisis Statistik Terlengkap dalam Software SPSS edisi 2, Jakarta: Salemba Infotek, 2014

Singgih Santoso, SPSS: Mengolah Data Statistik secara Profesional, Jakarta: PT. Elex Multi Komputindo, 1999.

Sugiono, Metode Penelitian Pendidikan, Bandung : Alfabeta, 2011.

Sugiyono, Metode Penelitian Kuantitatif dan Research \& Development, Bandung: Alfabeta, 2007.

Suharsini Arikunto.Prosedur Penelitian, Jakarta : PT Rineka Cipta. 2002.

Werner J. Severin and James W. Tankard, Jr., Teori Komunikasi, Jakarta: Kencana Prenada,2011.

Wikipedia, diakses pada 18 Desember 2016 Pukul 19.21 WIB.

Winarso, Herupuji, Sosiologi Komunikasi Massa, Jakarta: Prestasi Pustaka, 2005

Syamsir Salam, MS dan Jeanal Aripin, Metodologi Penelitian Sosial, Jakarta: UIN Jakarta Press, 2006. 